\title{
From the Present to the Past The Historical Dynamics of Wealth in Early Modern Europe
}

Katia Béguin

How do societies change, and how does wealth distribution become more unequal? How can we grasp these evolutions, beyond the Brownian motion of family destinies and the rise and decline of individuals? Economists have mobilized a range of circumstantial explanations to account for variations in the distribution of wealth: the impact of technical change, globalization, access to training and employment, and so on. Among these, Thomas Piketty has emphasized one, more lasting factor: the dynamic of the recapitalization of major estates, accumulated in the past and passed on through inheritance in a context of sluggish economic and demographic growth and low taxation on capital (in other words, the greater part of human history). ${ }^{1}$ Based on data covering the nineteenth and twentieth centuries, Piketty's demonstration supports the proposal he has already formulated elsewhere: a progressive taxation of capital as a benign means of correcting an excessive and harmful increase in patrimonial inequality. ${ }^{2}$

Beyond this prescriptive dimension of his work (to which no citizen can remain indifferent), the key factor here is the accentuation of inequality in patrimonial wealth, of which Piketty analyzes the long-term effects. This is especially

This article was translated from the French by Katharine Throssell and edited by Chloe Morgan and Nicolas Barreyre.

1. Thomas Piketty, Capital in the Twenty-First Century, trans. Arthur Goldhammer (Cambridge/London: Harvard University Press, 2014), 350-53.

2. Although he takes inequalities in income into account, Piketty's analysis mainly focuses on wealth, which is more concentrated than income. 
stimulating for historians, for this variable has the potential to reinvigorate largescale serial studies in economic and social history. For instance, the optimal conditions for increasing wealth, analyzed in Capital in the Twenty-First Century, were also clearly present in the early modern era: the period witnessed numerous wars; economic and demographic growth were localized (and most often reversible) exceptions; the distribution of wealth was very unequal; and the structure of taxation remained deeply regressive (indirect taxation was predominant, with extended exemptions from direct taxation, a late and incomplete emergence of universal taxation, and a lack of taxation on inheritance). ${ }^{3}$ The societies of Old Regime Europe thus offer an ideal case study to test the validity of the mechanisms of the hyperconcentration of wealth that benefit the most substantial fortunes. For all that, would it be relevant, or even possible, for an early modernist to conduct a study analogous to the one Piketty has carried out for the nineteenth and twentieth centuries? The characteristics just mentioned mean that there is a dearth of global taxation data, and so immediately rule out a simple transposition of his methods. Accustomed to circumventing these gaps in their documentation and dealing with less homogeneous sources, historians of the early modern era have approached this problem from a variety of perspectives. They have looked at systems of inheritance and customs regulating the succession of goods among heirs; familial and individual strategies for dealing with all kinds of patrimonial unpredictability (perpetuation, the increase or decline of a fortune in the medium term); or market transfers, markets, prices, and rates of return on assets.

Piketty's analysis also incorporates these explanatory factors. However, in his study the formal nature of political regimes (unless they implement corrections to patrimonial wealth, such as taxation on successions that is more than just symbolic), the legal framework for the transmission of goods, or the very procedures by which the wealthy consolidate their future estates to avoid the division and dispersion of their fortunes, weigh little in comparison with the background of greater returns on inherited capital. For Piketty, this context constitutes the decisive factor in the divergence of wealth. ${ }^{4}$ My goal is thus to explore the paths that allow historians to grasp the foundations of the processes-imperceptible at the level of individual behaviors, however elaborate-by which economic inequalities have increased. I also seek to understand whether such an approach would enable scholars to account for the extreme concentration of wealth in early modern societies more effectively. In what follows, I will begin by considering what is currently known about the nature of major fortunes during the early modern period and the conditions that enabled the largest among them to prosper, as well as the matrimonial and patrimonial practices that contributed to the accumulation of inheritances.

3. Of course, such conditions were not constant from the sixteenth to the end of the eighteenth century, nor were they common to all countries in early modern Europe. However, this situation does at least correspond to what was traditionally known as the "dark seventeenth century."

4. Piketty, Capital, 362 and 614, n. 26. 
I will then examine how we can test this hypothesis by combining the data available on stocks of wealth and those related to returns on assets, in order to integrate it into a historical analysis.

\section{The Renewal of Major Fortunes and the Long Term}

In theory, early modern societies brought together the principal conditions favorable to the perpetuation of major fortunes. There was a high and extremely concentrated stock of private transmissible wealth, and taxation was generally regressive (with an increasing level of indirect taxes on common consumable goods ${ }^{5}$ and a fundamental divide between taxpayers and non-taxpayers that scarcely varied from one country to another). Though the birth rate was high, equally high mortality rates contributed to channeling inheritance toward a reduced number of heirs, a situation reinforced by matrimonial practices and testamentary arrangements. Beyond sporadic and ephemeral initiatives, the lack of taxation on direct inheritance-which, even in France, was exempt from the centième denier, the registration fee of 1 percent imposed on other kinds of asset transfers-significantly favored the familial transmission of wealth, as did the legal and customary contexts. ${ }^{6}$

\section{The "Micro" Approach: Useful Points of Reference}

Beyond the few cases already studied in monographs, it is almost impossible to obtain an overall vision of the evolution of major fortunes over a period of two or three hundred years. This is as much for documentary and historiographical reasons as because of an overly rigid conception of social reproduction and the perpetuation of wealth, which would by no means imply an unvarying transmission of assets

5. The sumptuary taxes levied on the consumption of luxury goods were an exception to this regressive trend of indirect taxes. However, the product of these taxes remained a marginal part of overall tax revenue in France because their purpose was above all linked to social classification and control of appearance, at least until the Revolution. In England, the relative weight of sumptuary taxes in the overall tax revenue was larger. See: Daniel Roche, La culture des apparences. Une histoire du vêtement, XVII ${ }^{e}$-XVIII ${ }^{e}$ siècle (Paris: Fayard, 1989); Michèle Fogel, "Modèle d'État ou modèle social de dépense ? Les lois somptuaires de 1485 à 1660," in Genèse de l'État moderne. Prélèvement et redistribution, ed. Jean-Philippe Genet and Michel Le Mené (Paris: Éd. du CNRS, 1987), 227-35; Maxine Berg and Helen Clifford, "Luxury, Consumer Goods and British Taxation in the Eighteenth Century," in La fiscalità nell'economia europea, secc. XIII-XVIII, ed. Simonetta Cavaciocchi (Florence: Firenze University Press, 2008), 2:1101-14.

6. Legal and customary practices such as the retrait lignager directly aimed to encourage the conservation or the return into a family group of inherited assets that had been sold. They allowed the seller's next of kin to replace the buyer, on the condition that the latter be reimbursed, by virtue of the collective right of kinship over a family's patrimony. This right of retrait lignager could only be applied to assets with the legal status of real property, in other words, to patrimonial capital par excellence. See Robert Joseph Pothier, "Traité des retraits," in Traités sur différentes matières de droit civil appliquées à l'usage du barreau et de jurisprudence française (Paris/Orléans: Jean Debure/V ${ }^{\text {ve }}$ Rouzeau-Montaut, 1773), 1:707-905. 
from one generation to another. ${ }^{7}$ The analysis of stocks of wealth and the incomes they produce can teach us much in itself about the composition of fortunes and the respective weight of inherited or acquired assets, as long as they are studied with the necessary methodological rigor. It is not sufficient, and I must insist on this point, to class assets in an estate inventory by category, nor to calculate the sum of their estimated values to obtain an approximate measure of a fortune, nor even (though this is preferable) to compare this fortune with the entire estate actually shared among the heirs. This is only a worthwhile exercise if all the early devolutions of the estate, gifts made during the lifetimes of the fortune's owners, and civil and religious dowries given to children or indirect descendants are included in the calculated total. ${ }^{8}$ It is good to find that this rigorous approach, sometimes lacking in historical studies, appears self-evident in Piketty's book. It is all the more important as ante mortem donations are increasing and currently make up more than half of succession transfers. ${ }^{9}$

\section{Capital in the Early Modern Era: Significant Revisions}

A detailed knowledge of the composition of fortunes has invalidated once prominent hypotheses, including the theory that the nobility was almost exclusively made up of landowners and thus very vulnerable to fluctuations in the returns from this kind of capital, itself dependent on favorable weather conditions, harvests, and the sale of agricultural produce at good prices. ${ }^{10}$ The assets possessed by the wealthiest percentile, and even the wealthiest decile, of the early modern era (generally landed aristocracy, merchant bankers, major traders, and those in the highest public offices) were much more diverse. The fortunes extant at the point of death provide only a partial vision of these assets, since they reveal little about the income flows that previously fed into them. Moreover, part of these assets, including venal offices, trade stocks, and short-term debt securities, would have disappeared if the owner died at an advanced age. Indeed, although land and revenues from real estate occupied a decisive position in the very largest fortunes throughout Europe (with the exception of small city-states such as Venice or Genoa, where real estate

7. Robert Descimon, "Power Elites and the Prince: The State as Enterprise," in Power Elites and State Building, ed. Wolfgang Reinhard (Oxford: Oxford University Press, 1996), $101-21$.

8. For an explanation and an example of this method in use, see Daniel Dessert, "Pouvoir et finance au XVII ${ }^{\mathrm{e}}$ siècle: la fortune du cardinal Mazarin," Revue d'histoire moderne et contemporaine 23, no. 2 (1976): 161-81.

9. Piketty, Capital, 392-93.

10. Lawrence Stone, The Crisis of Aristocracy, 1558-1641 (Oxford: Clarendon Press, 1965); Davis Bitton, The French Nobility in Crisis, 1560-1640 (Stanford: Stanford University Press, 1969); Erlig Ladewig Petersen, "The Crisis of the Danish Nobility, 1580-1660," in Social Historians in Contemporary France: Essays from Annales, ed. Marc Ferro (New York: Harper and Row, 1972), 157-79. François Billacois, "La crise de la noblesse européenne (1550-1650). Une mise au point," Revue d'histoire moderne et contemporaine 23, no. 2 (1976): 258-77; Denis Crouzet, "Recherches sur la crise de l'aristocratie en France au XVI ${ }^{\mathrm{e}}$ siècle : les dettes de la maison de Nevers," Histoire, économie et société 1, no. 1 (1982): 1-51. 
was rare and property holdings were largely made up of urban palaces ${ }^{11}$ ), we now know that participation in financial activities, particularly lending to sovereigns and individuals, investment in commercial companies, and activities relating to trade and exchange, was by no means insignificant.

Far from being the feudal relics of an obsolete power, major fortunes regenerated themselves in the early modern era. With the growing importance of life at court, aristocrats migrated to the capitals, and the city house, urban mansion, or chateau near the royal residence became an obligatory component of fortunes in the major territorial states. This transformation had important consequences, for example, on the price of estates relatively close to Paris, which were rarely sold: potential buyers had to search for properties in an ever-increasing radius. Above all, the fortunes of the very wealthy became increasingly based on finance, influenced by wars that heightened states' need to borrow. In these societies where savings were highly concentrated, the monarchs' main creditors were unsurprisingly to be found among the most wealthy. They invested in short- and long-term loans through the intermediary of houses of financiers in France, monied companies in London, and bankers in Rome; they also took an interest in the levying of taxes granted by states in order to anticipate future tax revenues and avoid the costs of collection through consortia of financiers, merchants, and bankers (often the same people). ${ }^{12}$

The concentration of wealth thus increased, for a small fraction of aristocratic society, with the integration of assets created by the public authorities, securities, venal offices, and appointments. In states where it was legal or customary (such as Rome, France, or Castile), the development of venality in senior offices and appointments led to the private appropriation of these assets, generally by families who tended to bequeath rather than sell them. In any case, the ownership of the capital corresponding to the financing of these offices was protected, which in France resulted in an explosion in the market prices of the more prestigious among them. They quickly became inaccessible for social groups who could have acquired them only a century before, until this speculation was abruptly stopped in $1665 .{ }^{13}$ The

11. Jean-François Chauvard, La circulation des biens à Venise. Stratégies patrimoniales et marché immobilier (1600-1750) (Rome: École française de Rome, 2005).

12. Bartolomé Yun-Casalilla, introduction to The Rise of Fiscal States: A Global History, 1500-1914, ed. Bartolomé Yun-Casalilla and Patrick K. O’Brien (Cambridge: Cambridge University Press, 2012), 1-35; Patrick K. O'Brien, "Historical Conditions for the Evolution of a Successful Fiscal State: Great Britain and its European Rivals from the Treaty of Munster to the Treaty of Vienna," in Cavaciocchi, La fiscalità, 1:131-51. For an indepth analysis of this fiscal-financial system in France, which shared certain characteristics with other early modern states, see Daniel Dessert, Argent, pouvoir et société au Grand Siècle (Paris: Fayard, 1984).

13. Robert Descimon, "La haute noblesse parlementaire parisienne. La production d'une aristocratie d'État aux $\mathrm{XVI}^{\mathrm{e}}$ et XVII ${ }^{\mathrm{e}}$ siècles," in L'État et les aristocraties, XII ${ }^{e}-\mathrm{XVII}{ }^{e}$ siècle. France, Angleterre, Écosse, ed. Philippe Contamine (Paris: Presses de l'Ens, 1989), 357-84. The legal venality of judicial offices, established in 1604, served as a guarantee that families would be able to resign the office in favor of a third party, or to sell it in case of death, subject to the payment of an annual tax depending on the value of the office. 
restriction of access to senior court positions, which depended on royal favor and therefore in theory remained outside this intergenerational transmission, proceeded according to a parallel form of insurance: the king granted brevets de retenue, which consigned not the total market value of the office, but the part that would be reimbursed in case of disposition in favor of a new incumbent. ${ }^{14}$ The amount of these brevets, bestowed by the king, limited the economic prejudice to which families liable to be deposed were subject, or provided them with a mortgage security against which to borrow. The market value of the brevets of the most prestigious court offices and important provincial military administrations reached its height between the seventeenth and eighteenth centuries, confining them to an ever more restricted milieu. In conjunction with the lettres de survivance that guaranteed the transmission of an appointment to one's heirs, these exorbitantly valuable brevets froze the circulation of the major court offices, several of which were held in direct patrilineal succession from the reign of Louis XIV until the Revolution. Of course, access to the favors of the court had a cost, beginning with the sumptuary consumption in which courtiers were obliged to participate. Sometimes seen as the universal cause of the ruin or dependency of the court-based aristocracy, this cost above all served to broaden the gap between families that could maintain their rank and increase their capital, and those that could not.

Far from being purely honorific, these state-created assets must be taken into account in our study because they produced revenue, had a market value, and-just as much as lands and fiefdoms-formed part of the arrangements put in place by the very rich to increase and control their future wealth. The partial withdrawal of the rarest goods from redistribution or the resale market, along with the scheduled devolution of inheritance (which tended to have the same effect), has attracted the attention of historians, who have seen this as a major catalyst for the concentration of wealth.

\section{Matrimonial and Patrimonial Capitalizations: Two Factors Intensifying Fortune Gaps}

In a number of countries in early modern Europe (though not simultaneously), the very wealthy transformed their matrimonial and successional practices in order to cumulate inheritable wealth and ward off the main threats to its perpetuation: dispersal through division, squandering by a profligate heir, the vagaries of biology that might leave them without a successor, the danger of seizure and forced sales in case of insolvability, and finally the risks inherent to the market, that is, the risk of seeing the market value of their capital fluctuate downwards and thus decrease its returns. 


\section{Alliances, Captation of Inheritances, and Matrimonial Malthusianism}

Comparable strategies of alliance emerged throughout Europe, with the goal of marrying fewer children so that those who were destined to continue or increase the patrimonial strength of the lineage could be wed more advantageously. Wherever it can be observed, this phenomenon led to an increase in celibacy for second and younger sons, a rarefication of hypogamic unions for girls, an increase in the size of dowries, ${ }^{15}$ and intense competition over female heirs wherever there was a possibility of securing the wealth of a lineage lacking a male heir (to the point where single men without fortunes did not scorn the radical solution of kidnapping $\left.{ }^{16}\right)$. The private archives of the families that were victorious in this matrimonial battle still bear the traces of these accumulated estates, incorporated through alliances and inheritances.

Such practices exacerbated families' biological precarity: fewer marriages meant fewer potential heirs. The concentration of inheritances onto one principal heir was a high-risk strategy and produced effects similar to one of the later factors of wealth divergence analyzed in Capital in the Twenty-First Century: a low birth rate. The counterpart of this early modern shift in matrimonial practices was thus the growth of trusts or fiduciary reserves, a more radical way of concentrating inheritance coupled with the advance designation of heirs, which ultimately meant preventing future generations from disposing of the assets. Piketty observes the effects of these practices in the nineteenth century, which led Thomas Jefferson to deplore that the earth would belong to the dead and not the living. ${ }^{17}$ These substitutions héréditaires, or entails, have also been the object of renewed attention by early modernists, but they have posed substantial problems when it comes to estimating the value of the assets concerned.

15. Descimon has shown that the value of dowries among the high parliamentary nobility in Paris increased tenfold over the seventeenth century, doubling approximately every twenty years. See Descimon, "La haute noblesse."

16. Danielle Haase-Dubosc, Ravie et enlevée. De l'enlèvement des femmes comme stratégie matrimoniale au XVII ${ }^{e}$ siècle (Paris: Albin Michel, 1999); Michel Nassiet, Parenté, noblesse et États dynastiques, $X V^{e}-X V I^{e}$ siècles (Paris: Éd. de l'EHESS, 2000).

17. Piketty, Capital, 362-66 and 451-52. Similar arrangements were initiated by the fedecommesso in Italy, the mayorazgo in Spain, the substitution in France, and the entail in Britain. For an overview of the current state of research and an up-to-date bibliography on Mediterranean Europe, see: Jean-François Chauvard, Anna Bellavitis, and Paola Lanaro, "De l'usage du fidéicommis à l'âge moderne. État des lieux," Mélanges de l'École française de Rome. Italie et Méditerranée modernes et contemporaines 124, no. 2 (2012): 321-37; Jean-Pierre Dedieu, "Familles, majorats, réseaux de pouvoir. Estrémadure, XV XVIII ${ }^{\mathrm{e}}$ siècle," in Réseaux, familles et pouvoirs dans le monde ibérique à la fin de l'Ancien Régime, ed. Juan Luis Castellano and Jean-Pierre Dedieu (Paris: CNRs Éditions, 1998), 111-46; Marie-Laure Massei-Chamayou, "L'économie successorale dans Pride and Prejudice," Revue de la société d'études anglo-américaines des XVII et XVIII siècles 63 (2006): 99-116. 


\section{Substitutions, Trusts, Entails, Majorats: Inalienable, Unseizable, and Unevaluable Patrimonial Wealth}

The organization of patrimonies into trusts (fidéicommis) placed their successive beneficiaries in the position of trustees, living on the income of inalienable assets. Such assets could be neither sold nor used as collateral against loans without the express permission of the monarch, who set the normative frameworks for trusts (and their equivalents) and required them to be recorded and made public. Once capital was integrated into a trust, it became untouchable and could not be legally seized by creditors. ${ }^{18}$ Withdrawn from transactions that involved estimates or evaluation, it was effectively preserved from the fluctuations of its market value and frozen at its conventional value, set at the time of the trust's foundation. It is quite difficult to estimate the extent of wealth immobilized in this way, as the original value of the capital is often the only information available, even though it may have varied significantly over the course of two or three generations.

It is clear that an overwhelming proportion of real-estate capital and urban property was immobilized during the eighteenth century. It was precisely at this time that several states decided to limit the duration of trusts and/or confine their use to the aristocracy, in keeping with political economy's condemnation of the perfidious effects of this removal of assets from the commercial sphere. A considerable amount of real-estate assets belonging to the clergy, hospitals, and social assistance institutions were also frozen, protected from sale or seizure without authorization from the political authorities. ${ }^{19}$ This is a blind spot for historical observation, rather like successions to a single descendent without division or inventory. It can only be circumvented by converting the annual income from these assets (where available) into capital by adopting the methods and criteria of notaries, who were experts in such estimations. This implies connecting an approach based on stocks of wealth to one based on returns on assets in an almost artisanal manner. If nothing more, this would enable historians to understand whether these properties, the focus of highly complex matrimonial strategies and successional arrangements, in fact procured their owners a higher rate of return than others and contributed to the dynamic of inequality. The question of returns on possessions identified as assets, present in variable proportions in all large fortunes, is crucial to Piketty's work. He refutes the standard hypothesis of economic models based on an identical average rate of return on capital for all owners, however small or

18. As a result, creditors could only be paid with revenues produced by capital immobilized in a trust, and not with the capital itself.

19. Venice and Rome retained the possibility of substitution in perpetuity, but Austria and France limited the duration to two generations, Piedmont and Tuscany to four generations, and England to a twenty-year period following the death of the donor. See Chauvard, Bellavitis, and Lanaro, "De l'usage du fidéicommis." Revolutionary France, followed by most other states, outlawed such substitutions of heirs during the nineteenth century. 
large their fortune, and argues, to the contrary, that the inequality of returns on capital is another essential factor in the divergence of wealth distribution. ${ }^{20}$

\section{Rates of Return on Capital: A Catalyst for Wealth Divergence in the Early Modern Era?}

A study seeking to respond to this interrogation poses two essential problems: on the one hand, it requires a mastery of the market prices of equivalent goods from which extrapolations can be made (as notaries and other experts did in the past); on the other, it supposes being able to grasp which elements in these composite fortunes yielded the highest rates of return.

\section{Wealth Stocks and Income Flows: Problematic Conversions}

The apparent simplicity of this approach is deceptive. By referring to the prices set by experts-by notaries during the division of estates, for instance-without focusing on their evaluation procedures, one risks misunderstanding the disputes that arose over estimates that were considered flawed, or the differences between market prices and reported estimates. Yet the manuals used by notaries are not explicit on this point, and the regularities observed among the acts in practice represent the main source of information available (along with legal challenges). The main lines can be summed up as follows: in order to evaluate a fortune, notaries based their calculation on the returns on assets, which they multiplied by a factor corresponding to the delay in recuperating the capital. For example, a factor of twenty reflected the estimation of returns on rent from housing, land, or securities (the inverse of the nominal interest rates, 5 percent of annuity in this case). ${ }^{21}$ The operation became less simple as soon as it involved goods that conveyed status, prestigious judicial offices, titled lands with associated seigniorial rights, or rights of low or high manorial justice, which were included in calculations and sometimes gave rise to disputes over the division among heirs. The variations in agricultural productivity and prices of produce were such that an average annual rate of return fluctuating around 3.5 percent is usually considered to be correct for land, given the maintenance costs also involved. This rate has the inconvenience of being an average, however, and does not account for the potential superiority of large real estate holdings. Focused studies on these holdings have produced contradictory results, at least for those assets rendered inalienable. ${ }^{22}$

\section{Piketty, Capital, 430ff.}

21. Nicolas Lyon-Caen, "Un prix sans aménité. L’indemnisation des propriétaires parisiens à la fin de l'Ancien Régime," Histoire et mesure 28, no. 1 (2013): 75-106; Lyon-Caen, "L’immobilier parisien au XVIII siècle, un marché locatif ?," Histoire urbaine 43, no. 2 (2015): 55-70; Pierre Couperie and Emmanuel Le Roy Ladurie, "Le mouvement des loyers parisiens de la fin du Moyen Âge au XVIII ${ }^{\mathrm{e}}$ siècle," Annales ESC 25, no. 4 (1970): 1002-23. 
As for early modern financial assets, they yielded volatile returns that varied from one country to another and according to context, and are in any case impossible to reduce to an average rate. They thus provide an interesting vantage point in many respects. An overwhelmingly high proportion were already in the possession of owners of large fortunes (a ratio at least as high, if not higher, than that for real estate assets). They may have spread in their more mundane form as public securities among a public of small bondholders, but the bulk of long-term debt securities were in the hands of an elite (1-3 percent of subjects in most issuing countries). ${ }^{23}$ They thus channeled an increasing portion of the money raised by taxes into the hands of those who were very little taxed to begin with. Moreover, like all forms of participation in funding states at war, they could yield very high rates of return.

\section{Lending for War, a Source of Unparalleled Profits}

Even though the French case was extreme, loans to warring sovereigns evidently provided the most profitable investment opportunities for the wealthiest members of society. Military conflict led to a rapid rise in the cost of money, anticipated by the major holders of specie, who only opened their coffers on the promise of high rates of return and who provided most of the volume of capital urgently raised by the warring parties.

The gaps in actual returns between small and large bondholders can be measured by a micro approach, including in cases of selective default by the borrower. ${ }^{24}$ It is also necessary to examine the conditions of the loans in detail to fully measure the profitability of these investments. Indeed, it was usual to sell debt securities below par to avoid an increase in the rate of interest, especially as this was intrinsically linked to the rate for short-term loans, which became exorbitant at the end of prolonged conflict (around 20-25 percent in France in the 1650s). The difference between the nominal interest rate and the actual rate of return was particularly significant in France, but it could be observed in similar forms even in England, where premiums on issue created distortions between the capital actually paid by purchasers and the nominal value of securities. ${ }^{25}$ An example will provide an idea of the reality of the returns concealed by official interest rates. At the end of a long-term process of lowering legal interest rates (to 5 percent), the

23. There were approximately 150,000 rentiers in France at the time of Louis XIV's death, in a kingdom of some twenty million subjects. For England, the available figures show 10,000 in $1709-1710,40,000$ in 1720, and 60,000 on the eve of the Seven Years' War (1756-1763), out of a total population of almost ten million inhabitants. In both cases, and even after correcting for household size, the elites that initially received these annuities were exceedingly small.

24. See the calculations concerning defaults on payments for public annuities in France between 1640-1660 in Katia Béguin, Financer la guerre au XVII siècle. La dette publique et les rentiers de l'absolutisme (Seyssel: Champ Vallon, 2012), 104-38.

25. Gregory Clark, "Debt, Deficits, and Crowding Out: England, 1727-1840," European Review of Economic History 5, no. 3 (2001): 403-36; Béguin, Financer la guerre, 245-54. 
deterioration of lending conditions in late seventeenth-century France was such that during the Nine Years' War (1688-1697) the crown offered perpetual annuities (exclusively to those who already possessed securities) at the maximum rate of 8.33 percent, a rate that had already been considered usurious by the superintendent of finances, the Duke of Sully, at the dawn of the seventeenth century. The largest fortunes provided a significant proportion of short-term loans, which were the most profitable, via the intermediary of financiers who signed the contracts, meaning that their participation did not appear in notarial acts and inventories upon their decease, except accidentally or exceptionally. If this is taken into consideration, it could be argued that because of their counter-redistributive effects (intensified by the fact that they generally existed in tandem with indirect taxation), war and the public debt that it generated were powerful accelerators of wealth divergence in the early modern era.

Moving beyond this partial exploration of the conditions in which the mechanics of inequality were able to play out and reinforce the concentration of wealth would require a larger number of studies, mapping the distribution of the composite elements of major fortunes, the fluctuating returns they obtained for their owners, and their market prices or reported estimates. Would such an undertaking, complicated as it would be by the dispersion of sources, the widespread usage of intermediaries, and the concealment of actual returns, fundamentally change the analysis of historians, who are accustomed to attributing social reproduction to forces other than the combination of factors that allow capital to snowball? ${ }^{26}$ In fact, as the case of financial assets shows, this hypothesis concerning the dynamic of wealth has the advantage of encouraging a reexamination of phenomena that are too closely interconnected to be understood via a short-sighted study confined to a single subfield of history, whether political, social, institutional, or financial. The intense military activities of early modern states, with their range of fiscal and financial implications, were just as decisive a factor in the reproduction and concentration of capital as the distribution of positions at court, matrimonial and patrimonial strategies, legal and customary frameworks, and fiscal privileges. Above all, further analysis of this cumulative process and its extent over time would demonstrate that the durability and success of major patrimonial fortunes represented anything but the reproduction of an immobile and immutable society. Inherited capital maintained its superiority by embracing change.

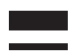

